\title{
Ethnoornithology and Bird Conservation in Afro-descendant Communities in the Brazilian Caatinga
}

\author{
Aurea Palloma Bezerra Barbosa Veras ${ }^{1}$, Cauê Guion de Almeida ${ }^{1}$, Lorena Lima de Moraes ${ }^{1}$, and Alexandre M. Fernandes ${ }^{1 *}$ \\ ${ }^{1}$ Federal Rural University of Pernambuco, Serra Talhada Campus, Pernambuco, Brazil. \\ *alexandre.mendesfernandes@ufrpe.br
}

\begin{abstract}
This paper investigates relationships between birds and the inhabitants of Afro-descendant communities in the Caatinga of northeastern Brazil, paying particular attention to conservation. Near the Refúgio de Vida Silvestre da Serra do Giz wildlife reserve, we interviewed 55 residents using semi-structured forms combined with free interviews and informal conversations. Residents reported 121 species in 43 families and 21 orders. They recounted what they knew about nesting, reproductive and social behaviors, diet, and bird conservation. The lack of reporting on several species of birds known from the Serra do Giz was probably because those birds are absent due to hunting and habitat destruction. This study demonstrates the importance of conducting ethnobiological studies for bird conservation and to record local traditional knowledge.
\end{abstract}

Received February 27, 2021

OPEN ठACCESS

Accepted November 18, 2021

DOI 10.14237/ebl.13.1.2022.1753

Published January 29, 2022

Keywords Birds, Ethnobiology, Quilombolas, Semiarid

Copyright (C) 2022 by the author(s); licensee Society of Ethnobiology. This is an open-access article distributed under the terms of the Creative Commons Attribution-NonCommercial 4.0 International Public License (https://creativecommons.org/licenses/by-nc/4.0), which permits non-commercial use, distribution, and reproduction in any medium, provided the original author and source are credited.

\section{Introduction}

Brazilian Afro-descendant rural communities, called quilombos, formed when escaped enslaved people or formerly enslaved people gathered on lands that were either donated, inherited, received as payment for services, purchased, or simply occupied before and after slavery was abolished. Regulation of such lands began in 2003, including the identification, delimitation, and titling of land. Quilombo territories have faced challenges from collective resistance; conflicts with other communities and political organizations; and most of all, a history of oppression (Castilho 2011). When enslaved Africans fled, they searched for freedom and dignity, maintaining the culture and lifestyle they were torn away from when they were enslaved. The exploitation of enslaved Africans and erasure of their cultures were typical of the racist European practice at that time. These practices denied enslaved peoples' rights that were guaranteed to people of European descent. The lack of those rights, especially of land ownership, even today results in conflicts when lands occupied by the quilombos are designated for protection. This is because the irregular (according to Brazilian law) establishment of traditional communities (both indigenous and quilombos) becomes complicated when the government establishes types of conservation units that prohibit human presence as a condition for their establishment (Chacpe 2014).

Ramos (2019), a popular educator and resident of a quilombo, recalls that in the African tradition the spoken word has power. Today, oral traditions and interactions are important for the construction, maintenance, and perpetuation of traditional knowledge and social relationships. Colonization in the Americas included the dehumanization of Indigenous and African peoples by the dominant white European culture that withheld respect for their traditional knowledge. This "civilizing" transformation was carried out by erasing the knowledge of those peoples of their origins and customs, which distanced them from their spiritual and physical relationships with land and their ecological belief systems (Lugones 2019). Here, one goal is to recognize traditional knowledge in quilombo communities. 
Conservation biology tends to not address communities that live in conservation areas, often viewing them as potential sources of conflict with conservation, especially under the assumption that local communities are incapable of developing rational use of their natural resources (Diegues 2000). However, local communities are often the repository of considerable knowledge pertaining to the local ecosystem that can strengthen and inform conservation sciences (Sayago and Bursztyn 2006). Traditional communities often have strong ties to their natural resources because they depend on them, and their relationship often figures largely in the symbolism they use when describing their community, jobs, resources, and resource management and even influences how their knowledge is taught to subsequent generations (Colchester 2000).

Ethnoornithological studies are being carried out around the world in recognition of contributions of traditional knowledge as tools for conservation (Alves et al. 2013; Barman et al. 2020; Lima et al. 2014). In Brazil, the first studies including ethnoornithological information were carried out when early colonizers began noting bird names and stories told to them by Indigenous peoples (Farias and Alves 2007). Around 1985, Jensen was the first to apply scientific methods to ethnoornithology in Brazil. Jensen (1985) found similarities between the bird classification systems of four groups of Indigenous peoples of the Amazon and the Linnean system of classification. Early ethnoornithology in northeastern Brazil began with observations and collections of 52 species in Pernambuco (Forbes 1881). Other ethnoornithological studies followed in northeastern Brazil, with themes such as ethnotaxonomy, ecology, conservation, hunting, illegal trade, bird omens, zootherapy, bird use (food, religion, pets), and beliefs and perceptions about birds (Alves et al. 2013; Araujo et al. 2005; Barbosa et al. 2010; Bezerra et al. 2013; Farias and Alves 2007; Galvagne-Loss et al. 2013, 2014).

In Brazil, there are still few studies that examine traditional knowledge about birds of Quilombo communities, of which a few focused on northeastern Brazil. Diniz et al. (2012) examined local ecological and taxonomical knowledge, habits, and customs of a Quilombo community in Pernambuco focusing on local bird community structure. Others examined ethnozoological knowledge overall, including the avifauna. Costa-Neto (2000) examined reproduction, social interactions, ecology, medicinal use, and hunting activities of a Quilombo community in Bahia. In that same community, Moura and Marques (2008) studied zootherapy based on local fauna and identified therapeutics prepared using local birds. This study aims to build on this scholarship by further documenting quilombola bird knowledge.

To better understand how people of the quilombos interacted with their local bird species, we asked participants about bird biology, conservation, and sociocultural importance of birds in northeastern Brazil. Additionally, we asked: 1) To what do the quilombolas attribute the loss of bird species? 2) Is knowledge of the quilombolas useful for developing effective conservation strategies?

\section{Methods}

Quilombola communities from the state of Pernambuco included in this study are Leitão da Carapuça in the municipality of Afogados da Ingazeira and Brejo de Dentro in the municipality of Carnaiba. Both are near the Refúgio de Vida Silvestre da Serra do Giz State Conservation Unit (310 ha, hereafter "reserve") The region is predominantly semiarid savanna (Santos et al. 2006; Veloso et al. 1991; Figure 1).

We collected information using semi-structured questionnaires, free-form interviews, and conversations (Huntington 2000). One member of each participating household was questioned, who selfidentified as the most knowledgeable about the local fauna. Questionnaires included the socio-demographic profile of the participant and information about birds including their natural history (reproduction, diet, migratory, sociality), aesthetics, cultural significance, uses, species that remain and those that have been lost, and their conservation.

Participants freely consented to the interviews. Bird species were identified during the interview by comparisons with animals and samples, photographs taken during the study, a photographic guide that was prepared for this study, and with help from specialists familiar with the local avifauna and their vernacular names (Alves and Rosa 2006).

Qualitative information was analyzed by the individual-based unity model, and included all information provided by the participant (Marques 1991). Information provided by the participants was compared with information available in the scientific literature of the region (Silvano and Jørgensen 2008). Twenty-five men and 30 women were interviewed, 


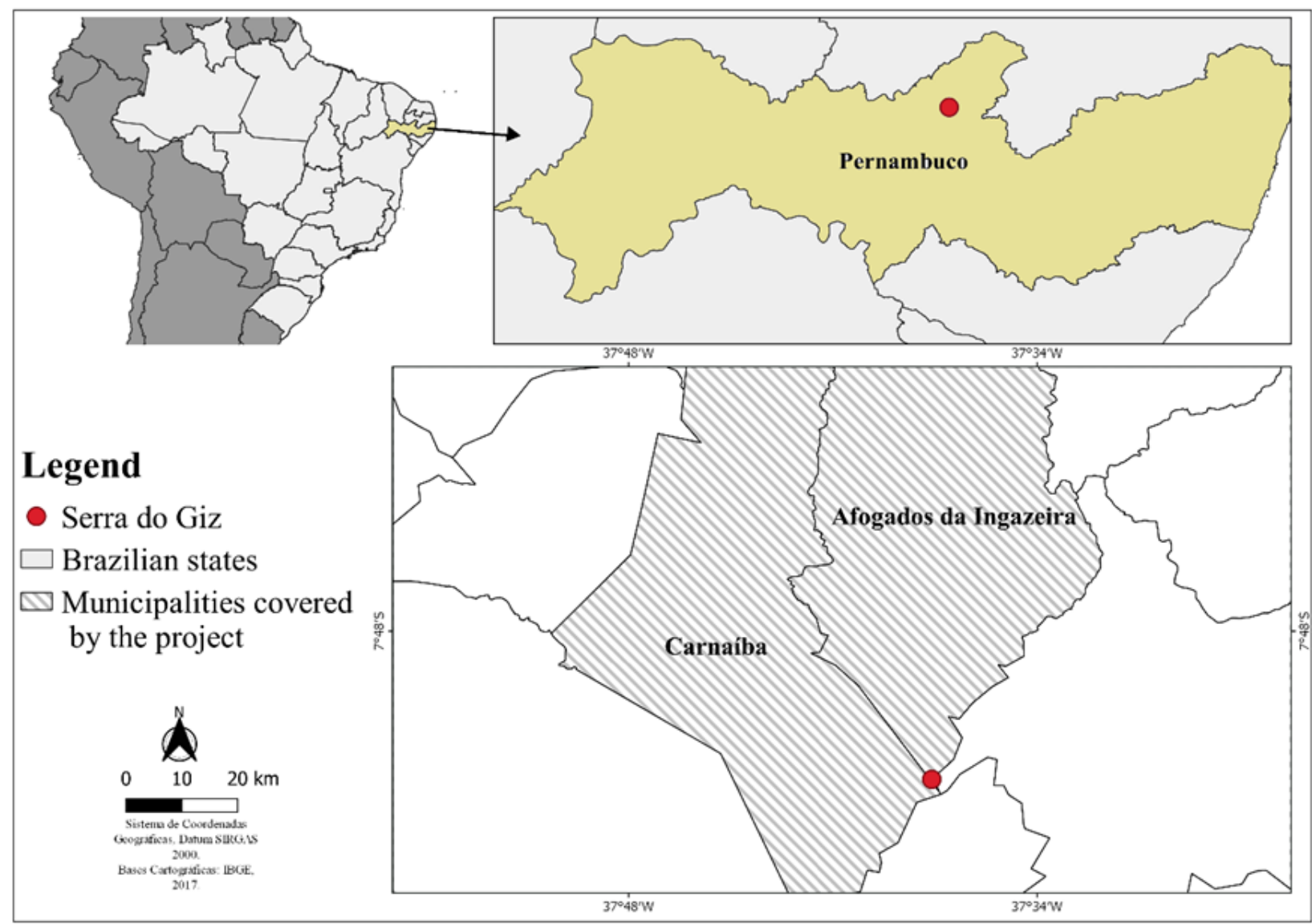

Figure 1 Location of the Refúgio da Vida Silvestre Serra do Giz, where we conducted the study.

with 32 in Leitão da Carapuça, and 23 in Brejo de Dentro. All participants, except one, were farmers. Socio-demographic profiles of the participants are provided in Table 1.

\section{Ethnoornithological Information as Reported by the Quilombolas}

Participants identified 120 species (43 families, 21 orders). Families most often cited were tanagers (Thraupidae), doves and pigeons (Columbidae), tyrant flycatchers (Tyrannidae), typical antbirds (Thamnophilidae), tinamous (Tinamidae), and blackbirds (Icteridae) (Table 2).

Most participants (82\%) knew a bird was nesting by its behavior, which may include having observed them carrying nesting material and duet singing. Participants (78\%) said birds tended to not re-use a nest, but rather build each nest in a new location. Some stated that the Pileated Finch (Lanio pileatus) and Southern Rough-winged Swallow (Stelgidopteryx ruficollis) defend their nests when a person approached. Participants indicated two unidentifiable species: a hummingbird that nests on spiny branches for protection, and another, probably a flycatcher, that nests close to bee or wasp nests. Several $(73 \%)$ stated that breeding occurred during the rainy season (January to June), when resources were abundant (Poulin et al. 1992), as is typical in the Caatinga (Hau et al. 2004).

Most participants (91\%) said 14 species migrate (seasonal movement to and away from an area) (Rappole 1995; Stotz et al. 1996; Table 2). When resources become scarce as summer begins, the birds leave. Participants $(45 \%)$ said that during the rainy season, the Eared Dove (Zenaida auriculata) travels in search of water and food, returning when beans (Phaseolus vulgaris) and Croton (Croton blanchetianus) (Euphorbiaceae) ripen. Euphorbiaceae (common in northeastern Brazil) are among the most important food plants for the dove (Antas 1987). The Lined Seedeater (Sporopbila lineola) migrates during the dry season and may go as far as the llanos of Venezuela 
Table 1 Socio-demographic parameters of residents of the community surrounding Serra do Giz.

\begin{tabular}{|c|c|c|c|}
\hline Characteristics & Category & Age Group & Participants (\%) \\
\hline \multirow[t]{14}{*}{ Age } & Men & $20-30$ & $2(3.6)$ \\
\hline & & $31-40$ & $7(12.8)$ \\
\hline & & $41-50$ & $5(9.1)$ \\
\hline & & $51-60$ & $6(10.9)$ \\
\hline & & $61-70$ & $1(1.8)$ \\
\hline & & $71-80$ & $2(3.6)$ \\
\hline & & $81-92$ & $2(3.6)$ \\
\hline & Women & $20-30$ & $4(7.3)$ \\
\hline & & $31-40$ & $7(12.8)$ \\
\hline & & $41-50$ & $6(10.9)$ \\
\hline & & $51-60$ & $6(10.9)$ \\
\hline & & $61-70$ & $1(1.8)$ \\
\hline & & $71-80$ & $4(7.3)$ \\
\hline & & $81-86$ & $2(3.6)$ \\
\hline \multirow[t]{3}{*}{ Marital status } & Married & & $35(63.7)$ \\
\hline & Single & & $12(21.8)$ \\
\hline & Widow(er)s & & $8(14.5)$ \\
\hline \multirow[t]{7}{*}{ Schooling } & Never studied & & $3(5.4)$ \\
\hline & Functionally illiterate & & $9(16.4)$ \\
\hline & Incomplete elementary and middle school & & $27(49.1)$ \\
\hline & Complete elementary and middle school & & $2(3.6)$ \\
\hline & Incomplete high school & & $9(16.4)$ \\
\hline & Complete high school & & $4(7.3)$ \\
\hline & Mobral & & $1(1.8)$ \\
\hline \multirow[t]{3}{*}{ Length of residence } & $<05$ years & & $5(9.1)$ \\
\hline & $05-10$ years & & $5(9.1)$ \\
\hline & $>10$ years & & $45(81.8)$ \\
\hline \multirow[t]{2}{*}{ Monthly income } & < Minimum salary ( US\$200) & & $46(83.6)$ \\
\hline & > Minimum salary & & $9(16.4)$ \\
\hline
\end{tabular}

(Silva 1995). Only one person said that the Plainbreasted Ground Dove (Columbina minuta) is apparently nomadic. Nomadic species simply move around and stay where they find food (Winkler et al. 2016).

Most participants recognized territoriality in the Great Kiskadee (Pitangus sulphuratus) and the Southern Lapwing (Vanellus chilensis). They consider the Great Kiskadee to be aggressive because it attacks other birds when defending its nest and will even chase much larger birds (Marchini and Ferraz 2014). The Southern Lapwing was said to often attack animals, including people, if they get too close to a nest (Costa 2002).

Most participants $(73 \%)$ said birds sing more in the early morning (after 05:00 h), and they suggested that they do so when the day is still cool (Andrade 1997; Nishida et al. 2012). A quarter of participants said mornings and afternoons provided the same opportunity for hearing birds, and $2 \%$ said the afternoon was best. All said that early mornings and late afternoons were the best time to observe birds.

The most difficult birds to see were the Smallbilled Tinamou (Crypturellus parvirostris) and the Whitetipped Dove (Leptotila verreauxi). Tinamous are always hard to see because they are well camouflaged and only their songs are heard. The dove is seldom observed, but when startled it flies away, making considerable noise while flapping its wings (Lima 2004).

Many participants remarked about birds imitating others, including the Turquoise-fronted Parrot (Amazona aestiva), the Blue-winged Macaw (Primolius maracana), the White-naped Jay (Cyanocorax gyanopogon), the Variable Oriole (Icterus pyrrhopterus), the Ultramarine Grosbeak (Cyanoloxia brissonii), the White- 


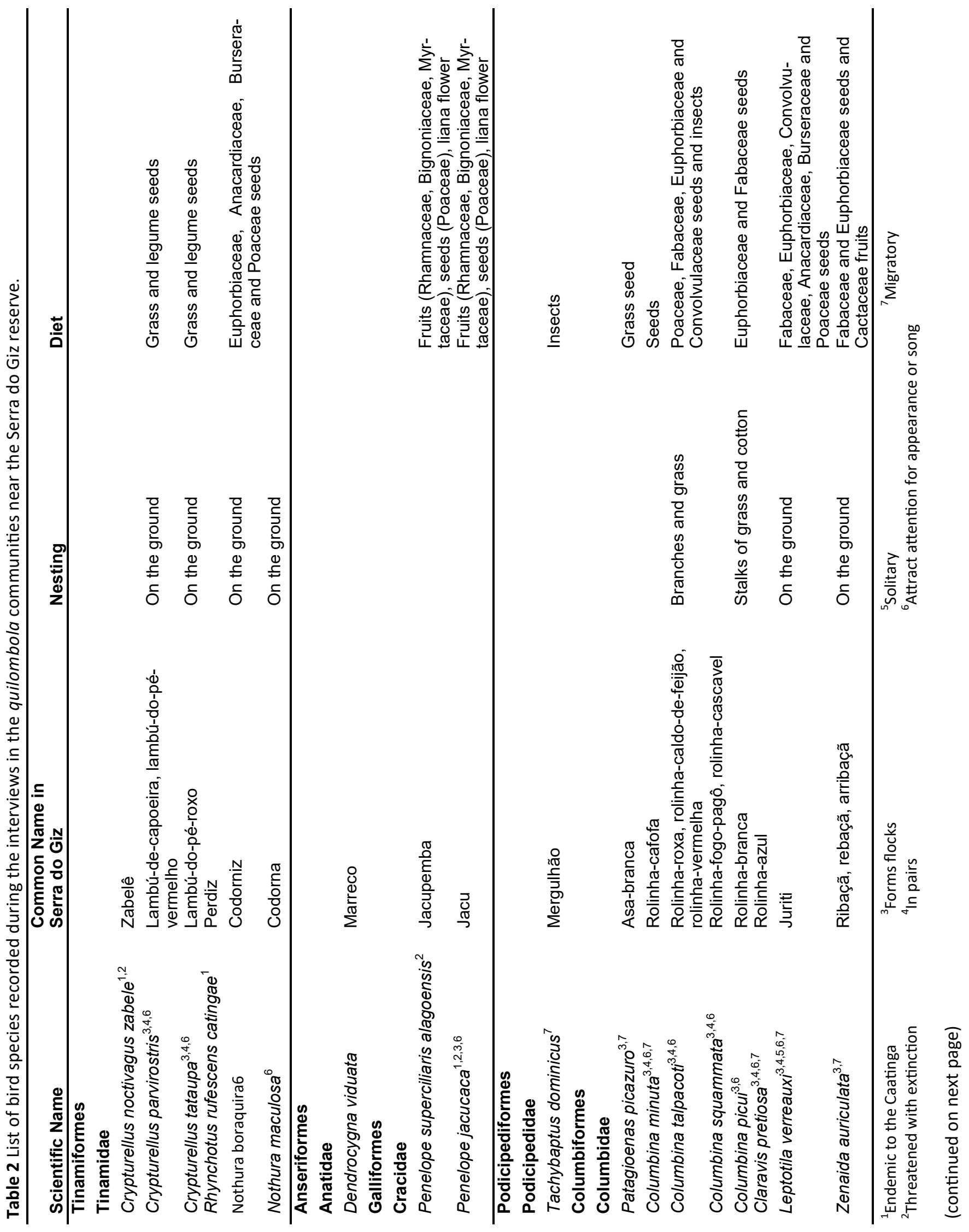


Etethobiolocy Letters Research Communications

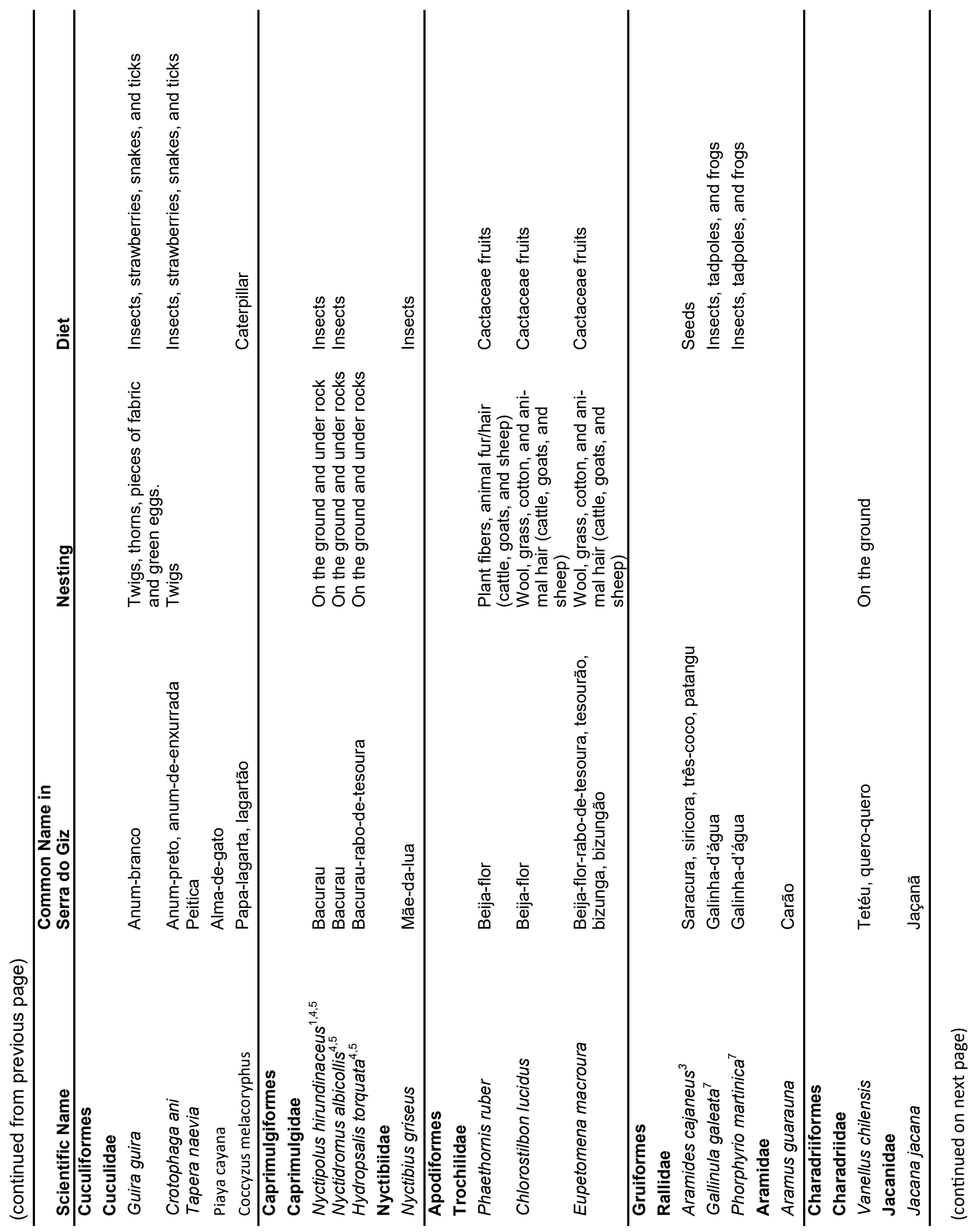




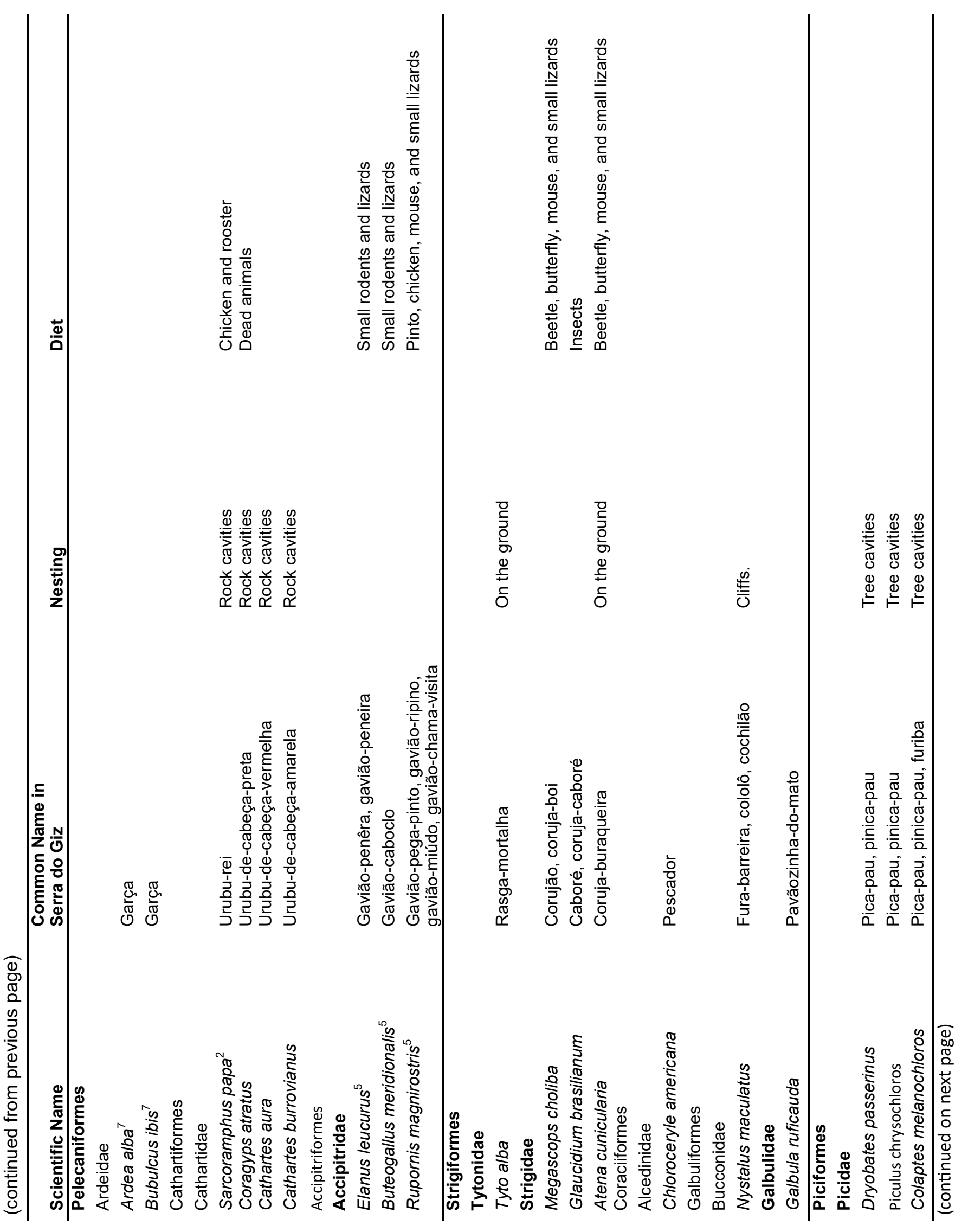




\section{(f) Ethnobiology Letters Research Communications}











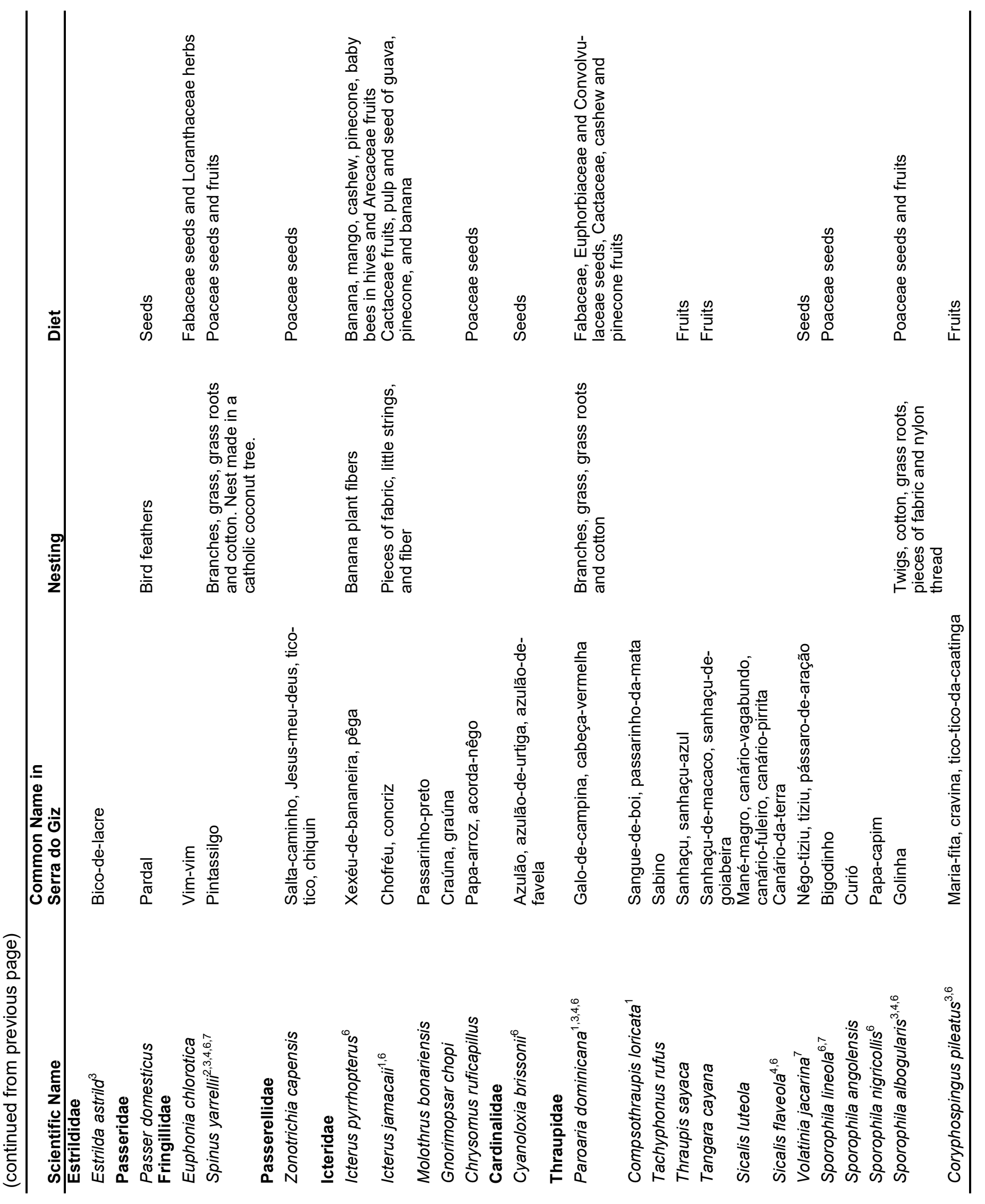


throated Seedeater (Sporophila albogularis), and the Rufous Bellied Thrush (Turdus rufiventris). All these species are known to imitate other bird species (Lima 2004; Sick 1997).

\section{Use and Factors that Led to the Disappearance of the Birds}

Most interviewees in the quilombos believed that hunters caught birds for their song, beauty, and intelligence; and so, the best singing birds and birds that talk (and presumably are smart) tend to be the most captured (songbirds and parrots) (Franco et al. 2012). Having pets was the main reason reported for capturing birds and we observed that this was common in rural communities throughout Brazil during this project. Birds are often captured for the pet trade as well (Alves et al. 2010). Thus, most participants stated that illegal hunting (for the pet trade or for food) was the main cause of bird declines, and which causes concern among the quilombolas because they recognize the ecological importance of the species, and that continued hunting can cause their demise.

Many participants knew of some species that were much more common in the past, nine of which are also threatened or endangered according to the Red Book of Endangered Brazilian Fauna (ICMBio 2018). Six species seen in the past are almost never seen today by the interviewees. Of these, one regional subspecies, (CR), the Rusty-margined Guan (Penelope superciliaris alagoensis), is critically endangered. Two parrots are near threatened (NT): locally, the Turquoise-fronted Parrot (Amazona aestiva) and globally, the Blue-winged Macaw (Primolius maracana). Three are vulnerable (VU): the White-browed Guan (Penelope jacucaca), Yellow-legged Tinamou (Crypturellus noctivagus), and Forbe's Blackbird (Anumara forbesi). Three other species are seldom seen by the interviewees. Of these, two are NT, the King Vulture (Sarcoramphus papa) and the White-browed Antpitta (Hylopezus ocbroleucus), and one is VU, the Yellowfaced Siskin (Spinus yarrellii).

Some stated that the Yellow-faced Siskin is only seen in the rainy season, while others said it was last seen about four years ago. Some more common birds that are not threatened are seldom seen. A participant stated that they last saw the Tataupa Tinamou (Crypturellus tataupa) eight years ago. They last saw the Chopi Blackbird (Gnorimopsar chopi) five years ago during the rainy season. The Saffron Finch (Sicalis flaveola) disappeared due to being captured for the pet trade. On the other hand, other birds they saw in the past, such as the Campo Troupial (Icterus jamacair) and Variable Oriole (Icterus pyrrhopterus), were recently seen again. Five interviewees said they thought their return was because the area was fenced in, and hunting was prohibited. Another 26 said that a strong, long, dry period (5-6 years) caused the population decline in those birds due to a lack of food and water. Beginning in 2018, rainfall increased again and so the birds returned.

Participants knew that hunting native birds is illegal, but hunting is not uncommon. Landowners often prohibit hunting. Some hunters avoid hunting in the reserve because they were concerned about being caught by enforcement officials. While hunting is less common than in the past, participants knew that hunting in the reserve continues.

\section{Importance of Birds}

Most participants $(71 \%)$ agreed that birds are important. Importance was classified as aesthetic $(59 \%)$, ecological $(20 \%)$, conservationist $(15 \%)$, and cultural $(7 \%)$. Participants felt that bird beauty and song brought joy to the Caatinga. Participants knew that birds were important for environmental services including pollination, seed dispersal, and consuming insects like crop pests or ticks on cattle and horses. One participant noted that some birds eat snakes and so help protect people from snake bites. Participants felt that conservation was important simply because birds have the right to freedom and life, just as people do. Participants said that birds were important culturally because birds figure into their belief systems and communities. They also stated that they knew stories that included birds and that they believed that birds are often associated with luck (both good and bad), tragedy, death, when people are arriving, and changing weather.

\section{Conservation Initiatives}

The Refúgio de Vida Silvestre Serra do Giz reserve, created in 2019, still has no management plans and there are no reserve rangers or guards that patrol the reserve. That being the case, involvement of the people of the local communities is very important for the protection of the reserve. Today, a single community member is responsible for guiding tourists and researchers within the reserve. Also, local residents observe hunters and outsiders (those not known to the local communities) within the reserve. They often report these infractions to the Instituto 
Brasileiro do Meio Ambiente e dos Recursos Naturais Renováveis (IBAMA), the Brazilian natural resources agency, which visited the region once during our study and recovered illegal captive birds in Afogados da Ingazeira and other nearby communities. Most interviewees were concerned about hunting and so they were interested in converting the area into a formal conservation unit to protect local biodiversity. They were also concerned about the preservation of ancient rock wall paintings that made the region archaeologically interesting and attracts tourists.

When we asked the participants in these quilombos what actions might be useful for conservation in the refuge, they provided a variety of answers:

1) IBAMA, military police, and public prosecutors should coordinate to catch and prosecute poachers (19 citations)

2) Hunting and capturing should be expressly forbidden (9 citations)

3) A law should be enacted to prohibit bird hunting ( 9 citations)

4) Education programs should teach community members that catching, killing, and illegal wildlife trade which are all detrimental to the existence of birds (3 citations)

5) Community members should take responsibility themselves and request that hunters cease their activities (2 citations). Yet, no suggestions were forthcoming about how this action could be carried out, nor how this might result in personal danger in attempting to prohibit hunting.

The following were recommended by one participant each.

6) Deforestation should be prohibited.

7) Pollution (in general, with no particular mention of kind) should be prohibited.

8) State and municipal governments should demand that the federal government install a wildlife unit in a nearby municipality and should take an active part in monitoring the refuge.

9) Trees should be planted to attract birds.

10) Remote (drone) monitoring should be used.

11) Signage should be used around the refuge to state that hunting is prohibited.

12) Hunting limits should be created rather than a complete ban. Nine of the participants had no particular suggestions for protecting birds. Surprisingly, quilombolas seldom visit the conservation unit despite its accessibility, while the main visitors come from more urban regions of the municipality or from nearby cities and other states. Interviewees also stated that they seldom visited the area to hunt or for agriculture or logging.

\section{Cultural Transmission of Ethnoornithological Knowledge}

Oral transmission of information is important for ethnoornithology as in all traditional ecological knowledge transmission. Vertical transmission of information about birds was reported by $62 \%$ of the participants $(\mathrm{n}=34)$, with fathers $(\mathrm{n}=24)$ reporting more than mothers $(n=9)$ or grandparents $(n=9$ for each sex). Horizontal transfer was less important as reported by the community $(24 \%, \mathrm{n}=13)$, with people reporting spouses $(\mathrm{n}=2)$, siblings $(\mathrm{n}=1)$, neighbors $(\mathrm{n}=1)$ and other contemporaries $(\mathrm{n}=10)$. Oblique transmission $(15 \%, \mathrm{n}=8)$ was usually mentioned by older, non-relatives $(\mathrm{n}=5)$ and teachers $(n=3)$. Several $(n=16,29 \%)$ reported that they learned about birds at least partly on their own through daily observations of their natural environment. Many of the participants (69\%) said that they shared their avian knowledge with others $(\mathrm{n}=$ 38).

\section{Conclusion}

We found that the people of the Quilombo communities near the refuge had some knowledge and interest in birds. Most were concerned with bird conservation and thought of a variety of reasonable plans to protect birds. Conservation measures should include the quilombolas so that they can help manage and become more knowledgeable about avian communities. Understanding that small communities know about birds and are concerned about their conservation can encourage management to include them, and other local communities, in their actions and strategies, and thereby also validate the local knowledge of these communities.

\section{Declarations}

Permissions: This study was carried out under the University of Pernambuco Ethics Committee (CAAE 89888018.2.0000.5207) and registered in the Brazilian Sistema Nacional de Gestão do Patrimônio Genético 
e do Conhecimento Tradicional Associado (SisGen)

under the registry number A6A6D4D.

Sources of funding: None declared.

Conflicts of Interest: None declared.

\section{References Cited}

Alves, R. R. N., and I. L. Rosa. 2006. From Cnidarians to Mammals: The Use of Animals as Remedies in Fishing Communities in NE Brazil. Journal of Ethnopharmacology 107:259-276. DOI:10.1016/j.jep.2006.03.007.

Alves, R. R. N., E. E. G. Nogueira, H. F. P. Araujo, and S. E. Brooks. 2010. Bird-Keeping in the Caatinga, NE Brazil. Human Ecology 38:147-156. DOI:10.1007/s10745-009-9295-5.

Alves, R. R. N., R. C. L. Leite, W. M. S. Souto, D. M. M., Bezerra, and A. Loures-Ribeiro. 2013. EthnoOrnithology and Conservation of Wild Birds in the Semi-Arid Caatinga of Northeastern Brazil. Journal of Ethnobiology and Ethnomedicine 9:1-12. DOI:10.1186/1746-4269-9-14.

Andrade, M. A. 1997. A Vida das Aves: Introdução à Biologia e Conservação. Acangaú/Líttera, Belo Horizonte, Brazil.

Antas, P. T. Z. 1987. A Nidificação da Avoante, Zenaida auriculata, no Nordeste do Brasil, Relacionada com o Substrato Fornecido Pela Vegetação. Revista Brasileira de Zoologia 3:467-470. DOI:10.1590/S0101-81751986000300006.

Araujo, H. F. P., R. F. P. Lucena, and J. S. Mourão. 2005. Prenúncio de Chuvas Pelas Aves na Percepção de Moradores de Comunidades Rurais no Município de Soledade PB, Brasil. Interciencia 30:764-769. Available at: http://ve.scielo.org/ scielo.php?script $=$ sci_arttext\&pid $=$ S0378-

18442005001200008. Accessed on September 8, 2020.

Barbosa, J. A. A., V. A. Nobrega, and R. R. N. Alves. 2010. Aspectos da Caça e Comércio Ilegal da Avifauna Silvestre por Populações Tradicionais do Semiárido Paraibano. Revista de Biologia e Ciências da Terra 10:39-49. Available at: https:// www.redalyc.org/articulo.oa?id=50016922004.

Accessed on September 8, 2020.
Barman, P. D., D. K. Sharma, J. Cockrem, M. Malakar, B. Kakati, and T. Melvin. 2020. Saving the Greater Adjutant Stork by Changing Perceptions and Linking to Assamese Traditions in India. Ethnobiology Letters 11:20-29. DOI:10.14237/ ebl.11.2.2020.1648.

Bezerra, D. M. M., H. F. P. Araujo, A. G. C. Alves, and R. R. N. Alves. 2013. Birds and People in Semiarid Northeastern Brazil: Symbolic and Medicinal Relationships. Journal of Ethnobiology and Ethnomedicine 9:1-12. DOI: 10.1186/1746-4269-9-3.

Chacpe, J. F. 2014. Territórios Quilombolas e Unidades de Conservação de Proteção Integral: Desafios da Conciliação na Administração Federal. Master Thesis, University of Brasilia, Brasília, Brazil. Available at: https://repositorio.unb.br/ handle/10482/15878. Acessed on November 10, 2021.

Castilho, S. D. 2011. Quilombo Contemporâneo: Educação, Família e Culturas. EDUFMT, Cuiabá, Brazil.

Colchester, M. 2000. Resgatando a Natureza: Comunidades Tradicionais e Áreas Protegidas. In Etnoconservação: Novos Rumos Para a Proteção da Natureza nos Trópicos, edited by A. C. Diegues, pp. 225-256. HICITEC/NUPAUB-USP, São Paulo, Brazil.

Costa, L. C. M. 2002. O Comportamento Interespecífico de Defesa do Quero-Quero, Vanellus chilensis (Molina, 1782) (Charadriiformes, Charadriidae). Revista de Etologia 4:95-108. Available at: http://pepsic.bvsalud.org/scielo.php? script $=$ sci_arttext\&pid $=$ S1517-

28052002000200002. Accessed on September 5, 2020.

Costa-Neto, E. M. 2000. Conhecimento e Usos Tradicionais de Recursos Faunísticos por uma Comunidade Afro-Brasileira. Resultados Preliminares. Interciencia 25:423-431. Available at: http://www.redalyc.org/articulo.oa?id=33905105. Accessed on September 7, 2020.

Diegues, A. C. 2000. Etnoconservação da Natureza: Enfoques Alternativos. In Etnoconservação: Novos Rumos Para a Proteção da Natureza nos Trópicos, edited by A. C. Diegues, pp. 1-46. HICITEC/NUPAUBUSP, São Paulo, Brazil. 
Diniz, W. J. S., C. N. Lima, R. M. Lyra-Neves, and W. R. T. Júnior. 2012. Estudo Etnoornitológico no Remanescente Quilombola Estivas, Garanhuns, Pernambuco. Paper Presented at the XXIX Congress of the Brazilian Society of Zoology. Salvador, BA, Brazil. Available at: https:// cbznabahia2012.files.wordpress.com/2012/04/

livro-de-resumos.pdf. Accessed on September 7, 2020.

Farias, G. B., and A. G. C. Alves. 2007. Aspectos Históricos e Conceituais da Etnoornitologia. Biotemas 20:91-100. DOI:10.5007/\%25x.

Forbes, W. A. 1881. Eleven Weeks in Northeastern Brazil. Ibis 23:312-362. DOI:10.1111/j.1474919X.1881.tb06589.x.

Franco, M. R., F. M. Câmara, D. C. C. Rocha, R. M. Souza, and N. J. F. Oliveira. 2012. Animais Silvestres Apreendidos no Período de 2002 a 2007 na Macrorregião de Montes Claros, Minas Gerais. Enciclopédia Biosfera 8:1007-1018. Available at: https://www.conhecer.org.br/enciclop/2012a/ ambientais/animais.pdf. Accessed on September 5, 2020.

Galvagne-Loss, A. T., E. M. Costa-Neto, and F. M. Flores. 2013. Ornitoáugures no Povoado de Pedra Branca, Santa Teresinha, Estado da Bahia, Nordeste do Brasil. Etnobiología 11:45-53. Available at: https://dialnet.unirioja.es/servlet/articulo? codigo $=5261788$. Accessed on September 8, 2020.

Galvagne-Loss, A. T., E. M. C. Neto, and F. M. Flores. 2014. Aves Silvestres Utilizadas Como Recurso Trófico Pelos Moradores do Povoado de Pedra Branca, Santa Teresinha, Bahia, Brasil. Gaia Scientia Volume Especial Populações Tradicionais:1 -14. Available at: http://periodicos.ufpb.br/ojs2/ index.php/gaia/index. Accessed on September 8, 2020.

Hau, M., M. Wikelski, H. Gwinner, and E. Gwinner. 2004. Timing of Reproduction in a Darwin's Finch: Temporal Opportunism Under Spatial Constraints. Oikos 106:489-500. DOI:10.1111/j.00301299.2004.13206.x.

Huntington, H. P. 2000. Using Traditional Ecological Knowledge in Science: Methods and Applications. Ecological Applications 10:1270-1274. DOI:10.1890/1051-0761(2000)010[1270:UTEKIS] 2.0.CO;2.
Instituto Chico Mendes de Conservação da Biodiversidade (ICMBio). 2018. Livro Vermelho da Fauna Brasileira Ameaçada de Extinção: Volume III Aves. ICMBio/MMA, Brasília, Brazil.

Jensen, A. A. 1985. Sistemas Indígenas de Classificação de Aves: Aspectos Comparativos, Ecológicos e Evolutivos. Ph.D. Thesis, University of Campinas, Campinas, Brazil. Available at: http:// repositorio.unicamp.br/jspui/handle/

REPOSIP/316048. Accessed on September 5, 2020.

Lima, J. R. B., R. R. Florêncio, and C. A. B. Santos. 2014. Contribuições da Etnozoologia para a Conservação da Fauna Silvestre. Revista Ouricuri 4:48 -67. Available at: https://www.revistas.uneb.br/ index.php/ouricuri/article/view/1121. Accessed on September 8, 2020.

Lima, P. C. 2004. Aves da Pátria da Leari. Atualidades Ornitológicas, Salvador, Brazil.

Lugones, M. 2019. Rumo a um Feminismo Decolonial. In Pensamento Feminista: Conceitos Fundamentais, edited by H. B. Hollanda, pp. 357377. Bazar do Tempo, Rio de Janeiro, Brazil.

Marchini, S., and K. M. P. M. B. Ferraz. 2014. Bichos da ESALQ: Quais São, Como Vivem e Como Lidar com os Animais Silvestres no Campus. ESALQ, Piracicaba, Brazil.

Marques, J. G. W. 1991. Aspectos Ecológicos na Etnoictiologia dos Pescadores do Complexo Estuarino-Lagunar Mundaú-Mangaba. Ph.D. Thesis, University of Campinas, Campinas, Brazil. Available at: http://repositorio.unicamp.br/handle/ REPOSIP/315947. Accessed on September 5, 2020.

Moura, F. B. P., and J. G. W. Marques. 2008. Zooterapia Popular na Chapada Diamantina: Uma Medicina Incidental? Ciência \& Saúde Coletiva 13:2179-2188. DOI:10.1590/S14138123200800090002 .

Nishida, S. M., F. K. Ubaid, R. S. O. Carvalho, and M. M. Quinalha. 2012. Que Bichos Vivem no Jardim Botanico do IB? Guia de Aves. Silvia Mitiko Nishida, Botucatu, Brazil.

Poulin, B., G. Lefebvre, and R. McNeil. 1992. Tropical Avian Phenology in Relation to Abundance and Exploitation of Food Resources. Ecology 73:2295-2309. DOI:10.2307/1941476. 
Ramos, F. 2019. Saberes Tradicionais como Fortalecimento da Comunidade. Revista Observatório Quilombola 4:11-20. Available at: http:// www.koinonia.org.br/oq/uploads/arquivo/ Artigo \%2003\%20-\%20Fabiana \% 20padronizado.pdf. Accessed on September 5, 2020.

Rappole, J. H. 1995. The Ecology of Migrant Birds: A Neotropical Perspective. Smithsonian Institution Press, Washington, DC.

Santos, H. G., P. K. T. Jacomine, L. H. C. Anjos, V. A. Oliveira, J. B. Oliveira, M. R. Coelho, J. F. Lumbreras, and T. J. F. Cunha, eds. 2006. Sistema Brasileiro de Classificação de Solos, 2nd edition. EMBRAPA-SPI, Rio de Janeiro, Brazil.

Sayago, D., and M. Bursztyn. 2006. A Tradição da Ciência e a Ciência da Tradição: Relações Entre Valor, Conhecimento e Ambiente. In Dimensões Humanas da Biodiversidade: O Desafio de Novas Relações Sociedade-Natureza no Século XXI, edited by I. Garay, and B. K. Becker, pp. 89-109. Editora Vozes, Petrópolis, Brazil.

Sick, H. 1997. Ornitologia Brasileira. Nova Fronteira, Rio de Janeiro, Brazil.
Silva, J. M. C. 1995. Seasonal Distribution of the Lined Seedeater Sporophila lineola. Bulletin of the British Ornithologistis' Club 115:14-21. Available at: https://www.biodiversitylibrary.org/part/76851\#/ summary. Accessed on September 5, 2020.

Silvano, R. A. M., and J. V. Jørgensen. 2008. Beyond Fishermen's Tales: Contributions of Fishers' Local Ecological Knowledge to Fish Ecology and Fisheries Management. Environment, Development and Sustainability 10:657-675. DOI:10.1007/s10668-0089149-0.

Stotz, D. F., J. W. Fitzpatrick, T. A. Parker III, and D. K. Moskovits. 1996. Neotropical Birds: Ecology and Conservation. University of Chicago Press, Chicago, IL.

Veloso, H. P., A. L. R. Rangel Filho, and J. C. A. Lima. 1991. Classificação da Vegetação Brasileira, Adaptada a um Sistema Universal. IBGE, Rio de Janeiro, Brazil.

Winkler, D. W., J. Shamoun-Baranes, and T. Piersma. 2016. Avian Migration and Dispersal. In Handbook of Bird Biology, 3rd edition, edited by I. J. Lovette, and J. W. Fitzpatrick, pp. 452-492. Wiley, Chichester, England. 